Check for updates

Cite this: RSC Adv., 2019, 9, 9449

Received 21st January 2019

Accepted 18th March 2019

DOI: 10.1039/c9ra00522f

rsc.li/rsc-advances

\section{Biotransformation of 4-methylcoumarins by cambial meristematic cells of Camptotheca acuminata†}

\author{
Yuhua Zhang, Jiayi Jiang, Ningbo Qin, Qian Zhang and Chunyan Yan (DD *
}

Cambial meristematic cell (CMC) suspension cultures were investigated as a new biotransformation system for the first time. Four 4-methylcoumarins substrates were transformed by CMCs of Camptotheca acuminata into four corresponding products, including 4,8-dimethylcoumarin-7-O- $\beta$-D-glucopyranoside (I-1), 4,7-dimethylcoumarin-6-O- $\beta$-D-glucopyranoside (II-1), 6-hydroxy-7-methoxyl-4- methylcoumarin (III-1), and 4,7-dimethylcoumarin-5-O- $\beta$-D-glucopyranoside (IV-1), of which I-1, II-1, and IV-1 were new compounds. In addition, the biotransformation time and the amount of substrate were investigated to compare the biotransformation rate and optimize the biotransformation conditions of the four substrates in C. acuminata CMCs suspension cultures. The results suggested C. acuminata CMCs were able to select glycosylate phenolic hydroxyl groups of 4-methylcoumarins I, II, and IV, with high regio- and stereoselectivity, but no corresponding glycoside of any phenolic hydroxyl group of compound III was detected. Simultaneously, the result also showed that the C. acuminata CMCs were able to transform the 7-hydroxy groups of substrate III to its corresponding methylated products. Furthermore, the monoamine oxidase (MAO) inhibition activities of biotransformed products were evaluated, and the data showed that all the products possessed good MAO inhibition activities in vitro. In conclusion, $C$. acuminata CMCs could be applied to glycosylation biotransformation as a novel plant-based system due to the successful application of bioconversion of exogenous coumarins.

\section{Introduction}

Monoamine oxidase (MAO) is an iron-containing enzyme that is abundant in noradrenergic nerve terminals and often involved in the degradation of biogenic amines. ${ }^{\mathbf{1}} \mathrm{MAO}$ is very important for the metabolism of several neurotransmitters and plays a significant role in the treatment of a number of psychiatric and neurological diseases, such as Parkinson's and Alzheimer's diseases. ${ }^{2,3}$ Coumarins are a large family of natural compounds and have a wide range of pharmacological activities, such as antitumor, antinociceptive, anticoagulant, anti-inflammatory, antimicrobial, antiviral, antioxidant, and antidepressant activities. $^{4}$ Recently, coumarin and its derivatives have been employed as MAO inhibitors. ${ }^{5-8}$ However, the pharmaceutical and clinical application of coumarins is restricted by their low water solubility. Coumarin glycosides have higher water solubility and are easily transported in biological systems and play important roles in pharmaceutical and clinical applications as target drugs. Glucosylation of coumarins by chemical methods has several limitations, including tedious process, poor regio-

School of Pharmacy, Guangdong Pharmaceutical University, Guangzhou 510006, China. E-mail: ycybridge@163.com; Fax: +86-20-39352052; Tel: +86-20-39352052

$\dagger$ Electronic supplementary information (ESI) available. See DOI: 10.1039/c9ra00522f or stereoselectivity, low yields, and serious environmental pollution. ${ }^{9}$ Nevertheless, coumarin glycosides could be obtained via efficient, mild, and regio- or stereoselective biotransformation of coumarins in plant cells. ${ }^{10}$

Biotransformation catalyzed by biocatalysts, including enzymes, whole cells, or microorganisms, is widely used for biological structural modification with regio- and stereoselectivity, and this process has great potential to generate soluble and non-toxic metabolites via mild reaction conditions and fewer steps. ${ }^{\mathbf{1 1 - 1 4}}$ Several studies on the bioconversion of coumarins in plant cells have been reported. Nine hydroxycoumarins with different substituted groups were biotransformed to investigate the substrate specificity and regioselectivity of coumarin glycosyltransferases in the hairy roots of Polygonum multiflorum. ${ }^{10}$ Zhou et al. reported that kellerin, a sesquiterpene coumarin derivative, was transformed into nine novel coumarin derivatives via dehydration, dehydrogenation, hydroxylation, and reduction using the callus of Angelica sinensis (Oliv.) Diels. ${ }^{15}$ In addition, the studies about transformation of polyphenol has been reported. SchmöLzer et al. reported integrated biocatalytic process for the nature polyphenol $C$-glucoside nothofagin. ${ }^{16}$ Phloridzin were synthesised using Malus domestica glycosyltransferase in engineered Pichia pastoris GS115. ${ }^{17}$ 
Cambial meristematic cells (CMCs), also known as plant stem cells, are innately undifferentiated cambium cell lines located in the meristems of plants and possess unlimited proliferation characteristics. ${ }^{\mathbf{1 8}}$ The performance of CMCs is far superior to that of dedifferentiated plant cells (DDCs) on the basis of faster growth rates, higher yields of secondary metabolites and lower variability. ${ }^{\mathbf{1 9}}$ Moreover, CMC suspension cultures can exhibit stable growth rates and growth properties on an industrial scale. ${ }^{19,20}$ This may likely be attributed to strikingly greater tolerance to shear stress, which limits the growth of cells and reduces cell aggregation in stirred tanks or air-lift bioreactors. The presence of small, abundant vacuoles within each $\mathrm{CMC}$ facilitates this phenomenon. ${ }^{\mathbf{2 0 , 2 1}}$ In our previous study, C. acuminata CMCs were induced for the first time. Furthermore, the up-regulation of IPI, G10H, ASA1, TSB, $T D C 1, T D C 2$, and $S T R$, which encode the key enzymes in the biosynthesis pathway of terpenoid indole alkaloids, resulted in the higher accumulation of camptothecin (CPT) and 10hydroxycamptothecin (HCPT) in C. acuminata CMCs than in $C$. acuminata DDCs. ${ }^{22}$ As a new plant culture, Camptotheca acuminata CMCs have not been studied as a biotransformation system to transform exogenous substrates. Therefore, we aimed to determine whether plant stem cells with higher enzymatic activity can be used for biotransformation.

In the present study, the biotransformation of 4-methylcoumarins by $C$. acuminata CMCs was reported for the first time. Our aim was to explore the potential of $C$. acuminata CMCs for biotransformation reactions and develop a new and sustainable system on biotransformation of active molecules by CMCs of plants. Meanwhile, MAO inhibitory activities of all biotransformed products were also evaluated. Furthermore, the biotransformation time and amount of substrates were optimized to increase the biotransformation efficiency.

\section{Results and discussion}

\section{Structures of substrates}

4-Methylcoumarins were synthesized by a simple and efficient protocol shown as Table 1.

7-Hydroxy-4,8-dimethylcoumarin (I). White solid, mp 263.8$265.3{ }^{\circ} \mathrm{C}$. HR-ESI-MS $m / z:[\mathrm{M}+\mathrm{H}]^{+} 191.0703 .{ }^{13} \mathrm{C}$ NMR $(125$ MHz, DMSO- $\left.d_{6}\right) \delta_{\mathrm{C}}: 160.5$ (C-2), 111.7 (C-3), 153.8 (C-4), 123.1 (C5), 110.7 (C-6), 158.9 (C-7), 109.9 (C-8), 152.8 (C-9), 112.0 (C-10), $18.2\left(4-\mathrm{CH}_{3}\right), 8.0\left(8-\mathrm{CH}_{3}\right) \cdot{ }^{23}$

6-Hydroxy-4,7-dimethylcoumarin (II). Yellow solid, mp 207.7-208.3 ${ }^{\circ} \mathrm{C}$. HR-ESI-MS $m / z:[\mathrm{M}+\mathrm{H}]^{+} 191.0705 .{ }^{13} \mathrm{C}$ NMR (125 MHz, DMSO- $d_{6}$ ) $\delta_{\mathrm{C}}: 160.2$ (C-2), 113.4 (C-3), 152.0 (C-4), 117.8 (C-5), 152.7 (C-6), 130.2 (C-7), 117.9 (C-8), 146.1 (C-9), 108.3 (C-10), $18.0\left(4-\mathrm{CH}_{3}\right), 16.2\left(7-\mathrm{CH}_{3}\right){ }^{24}$

6,7-Dihydroxy-4-methylcoumarin (III). Yellow solid, mp 199.5-201.3 ${ }^{\circ} \mathrm{C}$. HR-ESI-MS $m / z:[\mathrm{M}+\mathrm{H}]^{+} 193.0495 .{ }^{13} \mathrm{C}$ NMR (125 MHz, DMSO- $d_{6}$ ) $\delta_{\mathrm{C}}: 160.0$ (C-2), 109.6 (C-3), 152.8 (C-4), 119.8 (C-5), 149.7 (C-6), 146.2 (C-7), 115.6 (C-8), 153.8 (C-9), $114.5(\mathrm{C}-10), 18.1\left(4-\mathrm{CH}_{3}\right) .{ }^{25}$

5-Hydroxy-4,7-dimethylcoumarin (IV). White solid, mp 250.9-252.2 ${ }^{\circ} \mathrm{C}$. HR-ESI-MS, $m / z:[\mathrm{M}+\mathrm{H}]^{+}$191.0704. ${ }^{13} \mathrm{C}$ NMR (125 MHz, DMSO- $d_{6}$ ) $\delta_{\mathrm{C}}: 159.8$ (C-2), 107.7 (C-3), 154.6 (C-4),
156.4 (C-5), 111.9 (C-6), 142.8 (C-7), 111.9 (C-8), 154.9 (C-9), 106.5 (C-10), $23.5\left(4-\mathrm{CH}_{3}\right), 21.1\left(7-\mathrm{CH}_{3}\right) .{ }^{26}$

\section{Identification of transformed products}

After HPLC analysis, it was seen that four products were formed, followed by the appearance of four additional peaks at retention time of 16.94 (I-1), 16.99 (II-1), 17.80 (III-1) and 22.19 (IV-1) min, respectively (Fig. 1). Then, four products from the biotransformation of 4-methylcoumarins with $C$. acuminata CMCs were identified.

Compound I was transformed to I-1 in C. acuminata CMCs. I1 was obtained as a yellow solid, and its HR-ESI-MS spectrum showed a pseudo molecular ion peak at $m / z 353.1234[\mathrm{M}+\mathrm{H}]^{+}$ (calcd 353.1231 for $\mathrm{C}_{17} \mathrm{H}_{21} \mathrm{O}_{8}$ ), indicating a molecular formula of $\mathrm{C}_{17} \mathrm{H}_{20} \mathrm{O}_{8}$. IR (KBr) $v_{\max } 3509,2934,1722,1609,1383,1285$, $1076 \mathrm{~cm}^{-1}$. The ${ }^{13} \mathrm{C}$ NMR spectrum showed carbon signals of $\delta_{\mathrm{C}}$ 160.3, 158.0, 153.6, 152.0, 123.3, 114.1, 113.8, 111.6, 111.1, 18.2 and 8.3. The ${ }^{1} \mathrm{H}$ NMR spectrum showed proton signals of $\delta_{\mathrm{H}}$ $7.57(1 \mathrm{H}, \mathrm{d}, J=8.3 \mathrm{~Hz}), 7.15(1 \mathrm{H}, \mathrm{d}, J=8.3 \mathrm{~Hz})$ and $6.23(1 \mathrm{H}, \mathrm{d}, J$ $=1.1 \mathrm{~Hz}$ ). The ${ }^{13} \mathrm{C},{ }^{1} \mathrm{H}$ NMR and IR spectra indicated compound I-1 was a coumarin similar with compound I. In addition, the additional proton signals of $\delta_{\mathrm{H}} 4.96\left(1 \mathrm{H}, \mathrm{d}, J=7.2 \mathrm{~Hz}, \mathrm{H}-1^{\prime}\right)$, 3.20-3.36 (4H, m, H-2'-5') $3.69\left(1 \mathrm{H}, \mathrm{d}, J=11.4 \mathrm{~Hz}, \mathrm{H}-6^{\prime} \mathrm{a}\right)$, and $3.48\left(1 \mathrm{H}, \mathrm{m}, \mathrm{H}-6^{\prime} \mathrm{b}\right)$ and carbon signals of $\delta_{\mathrm{C}} 100.6,77.2,76.6$, $73.3,69.7$, and 60.7 were observed in the ${ }^{1} \mathrm{H}$ NMR and ${ }^{13} \mathrm{C}$ NMR spectra of compound I-1 (Table 2), which suggested the presence of a glucopyranosyl moiety in $\mathbf{I - 1}$. Comparison of the ${ }^{1} \mathrm{H}$ and ${ }^{13} \mathrm{C}$ NMR data with those of I revealed that compound I-1 is a glucoside of I (Table 2).$^{10}$ In the HMBC spectrum, the correlation of the anomeric proton signal at $\delta 4.96\left(\mathrm{H}-1^{\prime}\right)$ to the carbon signal at $\delta 158.0$ (C-7) indicated that the sugar was linked to C-7. The ${ }^{13} \mathrm{C}$ NMR chemical shift of the anomeric carbon, along with the ${ }^{1} \mathrm{H}$ NMR chemical shift and spin-spin coupling constant $(J=7.2 \mathrm{~Hz})$ of the anomeric proton, allowed for the identification of a $\beta$ glucopyranosyl moiety. Based on these data, the structure of compound I-1 was identified as 4,8-dimethylcoumarin-7-O- $\beta$-Dglucopyranoside, which is a new compound.

Compound II was biotransformed by C. acuminata CMCs to a new compound, namely compound II-1. Compound II-1 was obtained as a pale solid, with a molecular formula of $\mathrm{C}_{17} \mathrm{H}_{20} \mathrm{O}_{8}$ based on a pseudo-molecular ion peak at $m / z 353.1235[\mathrm{M}+\mathrm{H}]^{+}$ (calcd 353.1231 for $\mathrm{C}_{17} \mathrm{H}_{21} \mathrm{O}_{8}$ ) in HR-ESI-MS. IR (KBr) $v_{\max } 3365$, 2830, 1644, 1624, 1385, $1028 \mathrm{~cm}^{-1}$. The ${ }^{1} \mathrm{H}$ NMR and ${ }^{13} \mathrm{C}$ NMR data of compound II-1 exhibited an additional glucopyranosyl moiety at $\delta_{\mathrm{H}} 4.87\left(1 \mathrm{H}, \mathrm{d}, J=7.4 \mathrm{~Hz}, \mathrm{H}-1^{\prime}\right), 3.14-3.31(3 \mathrm{H}, \mathrm{m}, \mathrm{H}-$ $\left.2^{\prime}-4^{\prime}\right), 3.44\left(2 \mathrm{H}, \mathrm{m}, \mathrm{H}-5^{\prime}, 6^{\prime} \mathrm{a}\right)$, and $3.74(1 \mathrm{H}, \mathrm{dd}, J=11.4,4.1 \mathrm{~Hz}$, $\left.\mathrm{H}-6^{\prime} \mathrm{b}\right)$ and $\delta_{\mathrm{C}} 101.5,77.4,76.8,73.3,70.2,61.0$. Comparison of the ${ }^{1} \mathrm{H}$ and ${ }^{13} \mathrm{C}$ NMR data with those of II revealed that compound II-1 is a glucoside of II (Table 2). ${ }^{27}$ In the HMBC spectrum, the correlation of the anomeric proton signal at $\delta_{\mathrm{H}}$ $4.87\left(\mathrm{H}-1^{\prime}\right)$ to the carbon signal at $\delta_{\mathrm{C}} 152.1(\mathrm{C}-6)$ indicated that the sugar was linked to $\mathrm{C}-6$. The $\beta$-anomer of the glucose was determined by the anomeric carbon at $\delta_{\mathrm{C}} 101.5$, anomeric proton at $\delta_{\mathrm{H}} 4.87$, and coupling constant $(7.4 \mathrm{~Hz})$. Therefore, the structure of compound II-1 was assigned as 4,7-dimethylcoumarin-6- $O-\beta$-D-glucopyranoside. 
Table 1 Synthesis of four substrates

\begin{tabular}{llll}
\hline Reactant & Temperature $\left({ }^{\circ} \mathrm{C}\right)$ & Time $(\min )$ & Product \\
\hline
\end{tabular}<smiles>Cc1c(O)cccc1O</smiles>

45<smiles>Cc1cc(=O)oc2c(C)c(O)ccc12</smiles>

I<smiles>Cc1cc2oc(=O)cc(C)c2cc1O</smiles>

30<smiles>Cc1cc(=O)oc2cc(O)c(O)cc12</smiles>

III<smiles>Cc1cc(O)c2c(C)cc(=O)oc2c1</smiles>

Compound III-1, a yellow crystal $(\mathrm{MeOH})$, gave a molecular formula of $\mathrm{C}_{11} \mathrm{H}_{10} \mathrm{O}_{4}$ by HR-ESI-MS at $m / z 207.0650[\mathrm{M}+\mathrm{H}]^{+}$ (calcd 207.0652 for $\mathrm{C}_{11} \mathrm{H}_{11} \mathrm{O}_{4}$ ). The structure of III-1 was determined as 6-hydroxy-7-methoxyl-4-methylcoumarin based on the comparison of the NMR spectra with known compound. ${ }^{28}$

Compound IV-1, a pale solid, was assigned the molecular formula $\mathrm{C}_{17} \mathrm{H}_{20} \mathrm{O}_{8}$ on the basis of its HR-ESI-MS data at $\mathrm{m} / \mathrm{z}$ $353.1223[\mathrm{M}+\mathrm{H}]^{+}$(calcd 353.1231 for $\left.\mathrm{C}_{17} \mathrm{H}_{21} \mathrm{O}_{8}\right)$. IR $(\mathrm{KBr}) v_{\max }$ 3339, 2945, 1718, 1695, 1607, 1386, 1074, $1031 \mathrm{~cm}^{-1}$. The ${ }^{1} \mathrm{H}$ and ${ }^{13} \mathrm{C}$ NMR spectra of compound IV-1 were similar to that of compound IV, and the major differences were the presence of signals for a sugar residue, namely $\delta_{\mathrm{H}} 4.99(1 \mathrm{H}, \mathrm{d}, J=7.2 \mathrm{~Hz}, \mathrm{H}-$ $\left.1^{\prime}\right), 3.32\left(2 \mathrm{H}, \mathrm{m}, \mathrm{H}-2^{\prime}-3^{\prime}\right), 3.19\left(1 \mathrm{H}, \mathrm{t}, J=8.6 \mathrm{~Hz}, \mathrm{H}-4^{\prime}\right), 3.38(1 \mathrm{H}$, $\left.\mathrm{m}, \mathrm{H}-5^{\prime}\right)$, and $3.70\left(1 \mathrm{H}, \mathrm{d}, J=11.4 \mathrm{~Hz}, \mathrm{H}-6^{\prime}\right)$ and $\delta_{\mathrm{C}} 101.1,77.2$, $76.9,73.4,69.7,60.6$. The HMBC correlation of $\delta_{\mathrm{H}} 4.99\left(\mathrm{H}-1^{\prime}\right)$ to the carbon signal at $\delta_{\mathrm{C}} 155.7(\mathrm{C}-5)$ suggested that the sugar unit was linked to $\mathrm{C}-5$. The relative configuration of the glucose residue was deduced to $\beta$ on the basis of the coupling constant $(7.2 \mathrm{~Hz})$ and the anomeric carbon at $\delta_{\mathrm{C}} 101.1$. Thus, compound IV-1 was defined structurally as 4,7-dimethylcoumarin-5-O- $\beta$-Dglucopyranoside, and this is a new compound (Table 2).

\section{Effects of time course on 4-methylcoumarins biotransformation}

The biotransformation properties of 4-methylcoumarins by $C$. acuminata CMCs were evaluated and compared by time course experiments after incubation for $1,2,3,4,5,6$, or $7 \mathrm{~d}$, respectively. The co-culture time was different, according to the distinct target product during the biotransformation process by CMCs. As shown in Fig. 2, the biotransformation ratio of compound I significantly increased from 1-2 d and increased slightly from 2-7 d. In addition, CMCs produced the highest biotransformation rate of $3.59 \%$ after co-culture for $7 \mathrm{~d}$. Thus, the optimum incubation time of $\mathbf{I}$ was $7 \mathrm{~d}$ in C. acuminata CMCs. The bioconversion ratio of compounds II to II-1 declined from 1 to $2 \mathrm{~d}$, significantly increased from 2 to $5 \mathrm{~d}$, and decreased again after $6 \mathrm{~d}$ in CMCs. This may be due to the feedback of the products in the culture. The maximum bioconversion ratio from compounds II to II-1 was $9.89 \%$ in CMCs. Therefore, the optimal co-culture time of II was $5 \mathrm{~d}$ in $C$. acuminata CMCs. The biotransformation ratio of III fluctuated slightly over the entire incubation period, and the maximum biotransformation ratio was $1.27 \%$ at $6 \mathrm{~d}$ in CMCs. The biotransformation ratio of IV significantly increased until the $4^{\text {th }}$ day of culture. Therefore, the optimal incubation time of IV was $4 \mathrm{~d}$, with a maximum biotransformation rate of $6.32 \%$ in CMCs.

\section{Effect of substrate amount on the 4-methylcoumarins biotransformation}

The effects of different amounts of substrates on biotransformation were investigated in C. acuminata CMCs (Fig. 3). The 

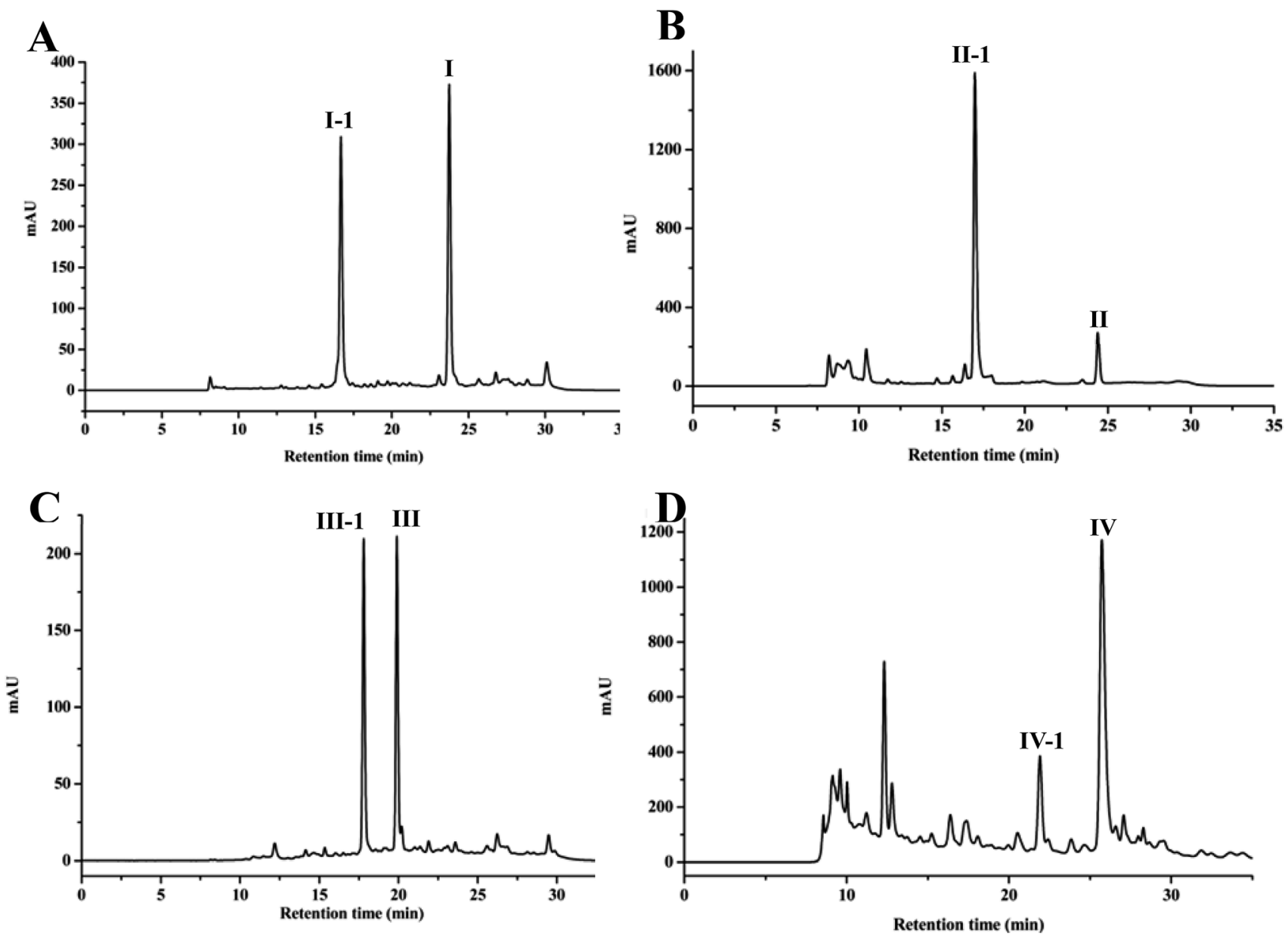

Fig. 1 HPLC chromatograms of biotransformation of (A) 7-hydroxy-4,8-dimethylcoumarin (I), (B) 6-hydroxy-4,7-dimethylcoumarin (II), (C) 6,7dihydroxy-4-methylcoumarin (III), (D) 5-hydroxy-4,7-dimethylcoumarin (IV). Substrates I, II, III and IV could be transformed into I-1, II-1, III-1 and IV-1 by C. acuminata CMCs, respectively.

yield of $\mathbf{I}-\mathbf{1}$ was $6.90 \%$ when $8 \mathrm{mg}$ of $\mathbf{I}$ was added to the CMCs. The yield of I-1 sharply declined as the concentration of $\mathbf{I}$ in CMCs increased. There was no obvious change in the yield of II$\mathbf{1}$ with increasing concentration of II, and the highest yield was $1.41 \%$ when $14 \mathrm{mg}$ of II were added. The yield of III-1 fluctuated slightly, and the maximum yield was $0.61 \%$ when $10 \mathrm{mg}$ III were added to the CMCs. The yield of IV-1 gradually decreased with increasing concentration of $\mathbf{I V}$, and the highest yield was $10.10 \%$ when $8 \mathrm{mg}$ of IV were added to the CMCs.

\section{Inhibition of MAO activity assay}

The MAO inhibition activities of all biotransformed products were evaluated in vitro using an MAO kit. As shown in Fig. 4, all products possessed good MAO inhibition activities, and the MAO inhibition activities of the four products slowly declined with increasing concentration of the tested products. Compound I-1 showed the best MAO inhibition activity.

Base on the structures of four products, we supposed that compound I, II and IV were transformed into I-1, II-1 and IV-1 by glycosylation, respectively, and compound III was transformed into III-1 by methylation (Fig. 5). The results from the biotransformation studies indicated that glycosylation of phenol hydroxyl groups of the three 4-methylcoumarins via $C$. acuminata CMCs was stereoselective and led to the formation of corresponding $\beta$-D-glucopyranosides. We speculated that compound III, with two phenolic hydroxyl groups, could be selectively methylated rather than glycosylated by the $\mathrm{C}$. acuminata CMCs, which was very different from the P. multiflorum hairy root cultures..$^{10}$ Moreover, the methylation conversion was regioselective at position C-7.

CMCs are innately undifferentiated cells located in the meristems of plants and can yield more natural products than DDCs. ${ }^{22,29} \mathrm{CMCs}$ induced by our group from C. acuminata were reported to be a better source of the anticancer drug camptothecin and its derivatives. ${ }^{22}$ Now, we report that $C$. acuminata CMCs also transform some exogenous substrates to their corresponding water-soluble and low-toxic derivative; therefore, $C$. acuminata CMCs could be used as a new transformation culture.

\section{Materials and methods}

\section{General experimental procedures}

1D and 2D- nuclear magnetic resonance spectroscopy (NMR) spectra were recorded on Bruker ARX-500 and ARX-600 
Table $2{ }^{1} \mathrm{H}(500 \mathrm{MHz})$ and ${ }^{13} \mathrm{C}$ NMR $(125 \mathrm{MHz})$ data for biotransformed products I-1, II-1 and IV-1 in DMSO- $d_{6}$

\begin{tabular}{|c|c|c|c|c|c|c|}
\hline Position & \multicolumn{2}{|r|}{ I-1 } & \multicolumn{2}{|r|}{ II-1 } & \multicolumn{2}{|r|}{ IV-1 } \\
\hline 3 & 111.6 & $6.23(\mathrm{~d}, 1.1)$ & 113.5 & $6.30(\mathrm{~d}, 0.8)$ & 113.3 & 6.14 (d. 1.0) \\
\hline 4 & 153.6 & & 153.4 & & 154.3 & \\
\hline 5 & 123.3 & $7.57(\mathrm{~d}, 8.3)$ & 110.3 & $7.38(\mathrm{~s})$ & 155.7 & \\
\hline 8 & 113.8 & & 117.7 & $7.22(\mathrm{~s})$ & 110.6 & $6.92(\mathrm{~s})$ \\
\hline 9 & 152.0 & & 147.9 & & 154.4 & \\
\hline 10 & 114.1 & & 117.9 & & 108.1 & \\
\hline $4-\mathrm{CH}_{3}$ & 18.2 & $2.39(\mathrm{~d}, 1.1)$ & 18.1 & $2.39(\mathrm{~d}, 0.8)$ & 23.9 & $2.60(\mathrm{~s})$ \\
\hline 7- $\mathrm{CH}_{3}$ & & & 16.3 & $2.30(\mathrm{~s})$ & 21.5 & $2.35(\mathrm{~s})$ \\
\hline $8-\mathrm{CH}_{3}$ & 8.3 & $2.24(\mathrm{~s})$ & & & & \\
\hline $4^{\prime}$ & 69.7 & $3.20(\mathrm{~m})$ & 70.2 & $3.14(\mathrm{~m})$ & 69.7 & $3.19(t, 8.6)$ \\
\hline $5^{\prime}$ & 77.2 & $3.36(\mathrm{~m})$ & 77.4 & $3.44(\mathrm{~m})$ & 77.2 & $3.38(\mathrm{~m})$ \\
\hline \multirow[t]{2}{*}{$6^{\prime}$} & 60.7 & $3.69(\mathrm{~d}, 11.4)$ & 61.0 & $3.74(\mathrm{dd}, 11.4,4.1)$ & 60.6 & $3.70(\mathrm{~d}, 11.4)$ \\
\hline & & $3.48(\mathrm{~m})$ & & $3.44(\mathrm{~m})$ & & $3.49(\mathrm{~m})$ \\
\hline Sugar-OH & & $5.44($ br s) & & $5.39(\mathrm{br} \mathrm{s})$ & & $5.43($ br s) \\
\hline Sugar-OH & & 5.18 (br s) & & 5.17 (br s) & & 5.27 (br s) \\
\hline Sugar-OH & & 5.11 (br s) & & $5.11(\mathrm{br} \mathrm{s})$ & & 5.18 (br s) \\
\hline Sugar-OH & & 4.60 (br s) & & $4.70(t, 5.3)$ & & 4.68 (br s) \\
\hline
\end{tabular}

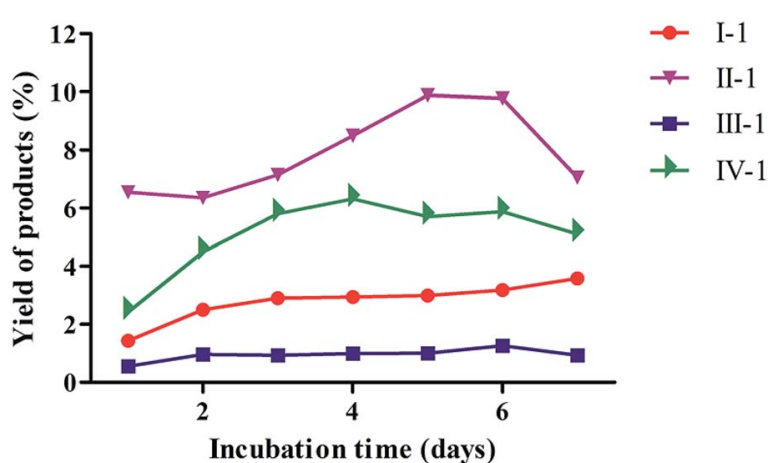

Fig. 2 Time course of the biotransformation of four substrates by $C$. acuminata CMCs. The product yield is expressed as a percentage relative to the total amount of reaction products.

spectrometers with tetramethylsilane (TMS) as an internal standard. High-resolution electrospray ionization mass spectroscopy (HR-ESI-MS) was employed on a Shimadzu LCMS-ITTOF (Kyoto, Japan). 2-Methyl resorcinol, 2-methyl hydroquinone, 5-methyl resorcinol, 1,2,4-benzenetriol, and phosphotungstic acid $\left(\mathrm{H}_{3} \mathrm{PW}_{12} \mathrm{O}_{40}\right)$ were purchased from Aladdin Industrial Corporation (Shanghai, China). The melting point was obtained on a micro-melting point apparatus (X-6, Tektronix, USA). An HPLC (1260 system, Agilent, USA) system equipped with a $\mathrm{C}_{18}$ column $(250 \times 4.6 \mathrm{~mm}, 5 \mu \mathrm{m}$; Phenomenex Synergi, USA) was used, and a semi-preparative RP-HPLC

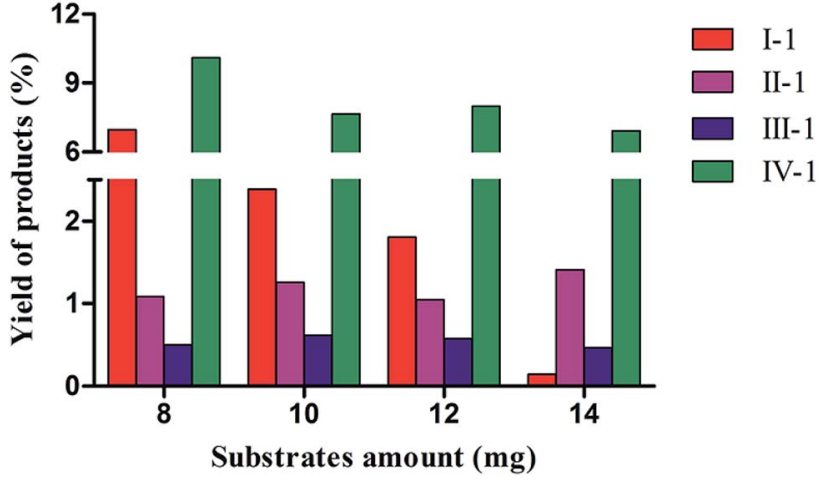

Fig. 3 The effect of substrate amount on product yield in the biotransformation of $C$. acuminata CMCs. The yield of products is expressed as a percentage relative to the total amount of reaction products.

method was conducted with a $\mathrm{C}_{18}$ column $(250 \times 10 \mathrm{~mm}, 5$ $\mu \mathrm{m}$; YMC Co., Ltd.). The rat liver was homogenized by a homogenizer (T10, IKA, Germany), and the mitochondria were isolated on a high-speed freezing centrifuge (TGL 20br, Anting, Shanghai, China). Phosphate buffer saline (PBS, pH 7.4), used to isolate the rat liver, was purchased from Haibiao Technology Company (Xiamen, China). A monoamine oxidase assay kit was purchased from Nanjing Jiancheng Bioengineering Institute (Nanjing, China). A Bradford protein quantitation assay kit was purchased from KeyGEN Biotechnology Company (Nanjing, China). 


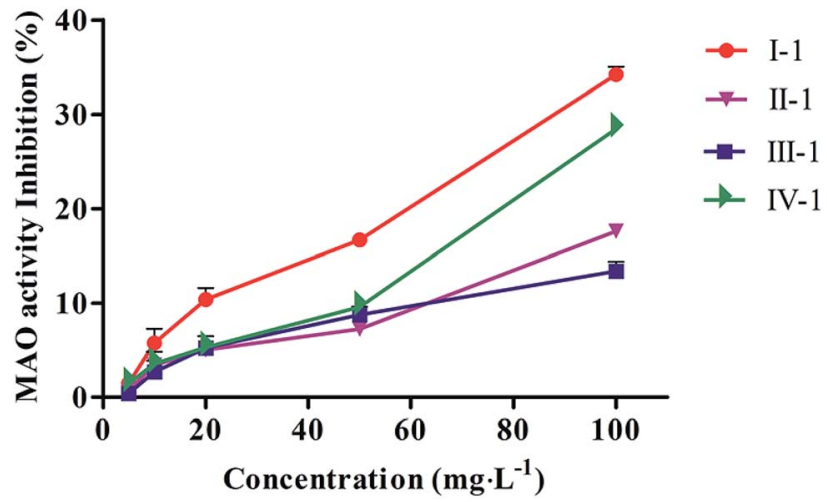

Fig. 4 MAO inhibitory activity of biotransformed products. Values were expressed as means \pm SD $(n=3)$.

\section{Synthesis of substrates}

A mixture of substituted phenol $(5 \mathrm{mmol})$, ethyl acetate (6 $\mathrm{mmol})$, and phosphotungstic acid $(0.5 \mathrm{mmol})$ in toluene $(5 \mathrm{~mL})$ was stirred for $45 \mathrm{~min}$ at $90-110{ }^{\circ} \mathrm{C}$ under reflux conditions (Table 1). Then, the mixture was dissolved in $75 \%$ ethanol and filtered immediately. The pure crystals of the products were obtained from the filtrate by recrystallization.

\section{Culture system and biotransformation procedures}

CMCs were induced from stems of C. acuminata and identified successfully in our research group previously, and $\mathrm{B}_{5}$ medium was determined as the best growth medium. ${ }^{22} \mathrm{CMCs}$ were cultured in liquid $\mathrm{B}_{5}$ medium supplemented with $1.0 \mathrm{mg} \mathrm{L}{ }^{-1}$ naphthalene-acetic acid (NAA), $0.5 \mathrm{mg} \mathrm{L}^{-1} 2,4-$ dichlorophenoxyacetic (2,4-D), $0.05 \mathrm{mg} \mathrm{L}^{-1}$ kinetin (KT), and $30 \mathrm{~g} \mathrm{~L}^{-1}$ sucrose. The $\mathrm{pH}$ of the liquid medium was adjusted to 5.75 , and the medium was sterilized at $120^{\circ} \mathrm{C}$ for $20 \mathrm{~min}$. Four grams of CMCs (fresh weight) were cultured in a $250 \mathrm{~mL}$ Erlenmeyer flask with $100 \mathrm{~mL}$ of the supplemented $\mathrm{B}_{5}$ medium, and the cultures were incubated at $25^{\circ} \mathrm{C} \pm 1{ }^{\circ} \mathrm{C}$ for 7 $\mathrm{d}$ on a rotatory shaker $(110 \mathrm{rpm})$. Eight milligrams of substrates were dissolved in DMSO at a final concentration of $20 \mathrm{mg} \mathrm{mL} \mathrm{m}^{-1}$ and were added to the above suspension cultures, respectively. The cultures were incubated for another $7 \mathrm{~d}$. Culture control groups consisted of equal amounts of cultures, medium and DMSO without substrates. Substrate control groups consisted of an equal amount of DMSO, substrate, and medium in the absence of cultures. A total of $220 \mathrm{mg}$ of each substrate were added to 27 bottles of suspension cultures to prepare the biotransformation products on a preparative scale.<smiles>Cc1cc(=O)oc2c(C)c(O)ccc12</smiles>

I

I-1<smiles>Cc1cc2oc(=O)cc(C)c2cc1OCCOC1OCC(O)C(O)C(O)C1Oc1cc2c(C)cc(=O)oc2cc1C</smiles><smiles>Cc1cc(=O)oc2cc(O)c(O)cc12</smiles>

III<smiles>Cc1cc(O)c2c(C)cc(=O)oc2c1</smiles><smiles>COc1cc2oc(=O)cc(C)c2cc1O</smiles>

III-1<smiles>Cc1cc(OC2OCC(O)C(O)C(O)C2O)c2c(C)cc(=O)oc2c1</smiles>

IV-1

Fig. 5 Possible biotransformation pathways of four substrates in C. acuminata CMCs. 
Extraction, isolation and purification of biotransformation products

After a $7 \mathrm{~d}$ incubation, the cultures and medium were separated by filtration. The medium was extracted three times with equal volumes of ethyl acetate (EtOAc) and $n$-butyl alcohol $(n-\mathrm{BuOH})$, respectively. The cultures were dried at $55{ }^{\circ} \mathrm{C}$ and extracted with methanol $(\mathrm{MeOH})$ three times. All extracts were evaporated to dryness and analyzed by HPLC. The EtOAc and MeOH extracts were combined and subjected to silica gel column chromatography with a gradient mixture of petroleum ether and EtOAc (50:1, $30: 1,20: 1,15: 1,8: 1,2: 1,1: 1)$ as the eluent. The eluate was further purified by RP-HPLC to afford four biotransformation products. The structures of the biotransformed products were established via chemical and spectroscopic methods.

\section{Optimization studies}

Biotransformation time. In order to improve the conversion ratio of substrates, the optimal incubation time was evaluated. Four grams of C. acuminata CMCs (fresh weight) were cultured in a $250 \mathrm{~mL}$ Erlenmeyer flask with $100 \mathrm{~mL}$ medium and mixed via rotatory shaker $(110 \mathrm{rpm})$ for $7 \mathrm{~d}$ at $25{ }^{\circ} \mathrm{C} \pm 1{ }^{\circ} \mathrm{C}$. Eight milligrams of substrates dissolved in DMSO were added to above suspension cultures and incubated for 1, 2, 3, 4, 5, 6, or 7 $\mathrm{d}$, respectively. The mixtures were analyzed by an HPLC equipped with an ultraviolet detector at $210 \mathrm{~nm}$. The mobile phases were $\mathrm{MeOH}$ and $0.1 \%$ trifluoroacetic acid (TFA) and were programmed as follows: a linear gradient from $30: 70(\mathrm{v} / \mathrm{v})$ to $75: 25(\mathrm{v} / \mathrm{v})$ in $20 \mathrm{~min}$, followed by a linear gradient from $75: 25$ $(\mathrm{v} / \mathrm{v})$ to $30: 70(\mathrm{v} / \mathrm{v})$ in $5 \mathrm{~min}$, and finally a gradient of $30: 70(\mathrm{v} / \mathrm{v})$ in $10 \mathrm{~min}$. The flow rate was $1.0 \mathrm{~mL} \mathrm{~min}^{-1}$, and the column temperature was $25^{\circ} \mathrm{C}$.

Substrates concentrations. The transformation ratio of substrates was determined for different amounts of substrate. First, 4 grams of $C$. acuminata CMCs (fresh weight) were cultured in a $250 \mathrm{~mL}$ Erlenmeyer flask containing $100 \mathrm{~mL}$ of medium, and the cultures were incubated at $25{ }^{\circ} \mathrm{C} \pm 1{ }^{\circ} \mathrm{C}$ for 7 $\mathrm{d}$ on a rotatory shaker (110 rpm). Next, 8, 10, 12, or $14 \mathrm{mg}$ of substrates dissolved in DMSO were administered to above suspension cultures, respectively. The cultures were then incubated for $7 \mathrm{~d}$. The mixtures were analyzed by HPLC as described above.

\section{Monoamine oxidase inhibiting activity tests}

Isolation of mitochondria. Mitochondria were isolated from a rat liver, according to a previously reported method with slight modifications. ${ }^{30,31} \mathrm{~A}$ female SD rat (220 g) was purchased from Guangzhou University of Chinese Medicine Animal Experimentation Center (Certificate: SCXK2013-0020) and euthanized. The liver was quickly excised and rinsed with PBS (pH 7.4). Two grams of liver tissue were minced with scissors and placed into a tube containing $80 \mathrm{~mL}$ of $0.3 \mathrm{M}$ sucrose. The mixture was transferred into a homogenizer and homogenized for $2 \mathrm{~min}$. The liver homogenate was centrifuged at $1000 \mathrm{~g}$ for $10 \mathrm{~min}$, and then the supernatant was further centrifuged at $10000 \mathrm{~g}$ for
$30 \mathrm{~min}$ at $4{ }^{\circ} \mathrm{C}$ to obtain the mitochondrial precipitate. The precipitate was rinsed with $\mathrm{PBS}$ ( $\mathrm{pH} 7.4$ ), and then suspended in $20 \mathrm{~mL}$ of PBS ( $\mathrm{pH} 7.4$ ). The mitochondria protein concentration was measured via Bradford protein quantitation assay. ${ }^{32}$ The standard curve of protein was obtained as $Y=0.026 X-0.0402$ $\left(R^{2}=0.9999\right)$, where $Y$ indicates the absorbance at $595 \mathrm{~nm}$, and $X$ indicates the concentration of protein.

Monoamine oxidase inhibitory activity assay. Biotransformed products were dissolved in DMSO to a concentration of $200 \mathrm{mg} \mathrm{L}^{-1}$, and their MAO inhibitory activities at final concentrations of $5 \mathrm{mg} \mathrm{L}^{-1}, 10 \mathrm{mg} \mathrm{L}^{-1}, 20 \mathrm{mg} \mathrm{L}^{-1}, 50 \mathrm{mg} \mathrm{L}^{-1}$ and $100 \mathrm{mg} \mathrm{L}^{-1}$ were evaluated using a monoamine oxidase assay kit.

\section{Conclusion}

The biotransformation of 4-methylcoumarins was carried out by C. acuminata CMCs for the first time, and four products, including three new compounds, were produced. The biotransformation time and the amount of substrate were optimized to obtain high yields. Furthermore, MAO inhibition activities of transformed products were evaluated. In conclusion, the CMCs could be used as a promising biotransformation system, which has immense potential to produce biologically active compounds by glycosylation. The enzymes catalyzed the transformed reactions in C. acuminata CMCs with high regioand stereoselectivity. The characterization of enzymes that catalyzed the glycosylation and methylation of coumarins is now in progress.

\section{Conflicts of interest}

There are no conflicts to declare.

\section{Acknowledgements}

This study was funded by the National Natural Science Foundation of China (No. 81102779), the Guangdong Natural Science Foundation (No. 9451022401003453) and the Innovative and Upgrading Schools Project of Guangdong Province (No. 2017KZDXM048).

\section{References}

1 K. Chen, D. P. Holschneider, W. H. Wu, I. Rebrin and J. C. Shih, J. Biol. Chem., 2004, 279, 39645-39652.

2 H. H. Fernandez and J. J. Chen, Clin. Neuropharmacol., 2007, 30, 150-168.

3 P. Riederer, W. Danielczyk and E. Grunblatt, Neurotoxicology, 2004, 25, 271-277.

4 P. O. Patil, S. B. Bari, S. D. Firke, P. K. Deshmukh, S. T. Donda and D. A. Patil, Bioorg. Med. Chem., 2013, 21, 2434-2450.

5 A. Fonseca, M. J. Matos, J. Reis, Y. Duarte, M. Gutiérrez, L. Santana, E. Uriarte and F. Borges, RSC Adv., 2016, 6, 49764-49768.

6 M. J. Matos, S. Vazquez-Rodriguez, E. Uriarte, L. Santana and D. Viña, Bioorg. Med. Chem., 2011, 21, 4224-4227. 
7 S. Serra, G. Ferino, M. J. Matos, S. Vázquezrodríguez, G. Delogu, D. Viña, E. Cadoni, L. Santana and E. Uriarte, Bioorg. Med. Chem., 2012, 22, 258-261.

8 D. Viña, M. J. Matos, M. Yáñez, L. Santana and E. Uriarte, Med. Chem. Commun., 2012, 3, 213-218.

9 D. Chen, R. Chen, K. Xie, T. Yue, X. Zhang, F. Ye and J. Dai, Org. Lett., 2018, 20, 1634-1637.

10 L. Zhou, T. Tian, B. Xue, L. Song, L. Liu and R. Yu, Biosci., Biotechnol., Biochem., 2012, 76, 1008-1010.

11 T. I. Kylosova, A. A. Elkin, V. V. Grishko and I. B. Ivshina, J. Mol. Catal. B: Enzym., 2016, 123, 8-13.

12 S. G. Musharraf, J. Uddin, M. Akhter, M. Parvez, Saifullah, S. Khan, S. Yousuf, S. Khan and M. I. Choudhary, J. Mol. Catal. B: Enzym., 2012, 82, 80-85.

13 M. Y. Rather, S. Mishra, V. Verma and S. Chand, Bioresour. Technol., 2012, 107, 287-294.

14 X. L. Xin, G.-J. Fan, Z. Sun, N. Zhang, Y. Li, R. Lan, L. Chen and P. P. Dong, J. Mol. Catal. B: Enzym., 2015, 122, 141-146.

15 D. Zhou, N. Li, Y. H. Zhang, C. Y. Yan, K. Jiao, Y. Sun, H. Ni, B. Lin and Y. Hou, RSC Adv., 2016, 6, 97302-97312.

16 K. SchmöLzer, M. Lemmerer and B. Nidetzky, Biotechnol. Bioeng., 2018, 115, 545-556.

17 T.-J. Zhang, J.-Q. Liang, X.-Y. Wei, P.-X. Wang, Y. Wu, S. Pen and M.-T. Fan, Process Biochem., 2017, 59, 187-193.

18 Z. H. Ye, Annu. Rev. Plant Biol., 2002, 53, 183-202.

19 E.-K. Lee, Y.-W. Jin, J. H. Park, Y. M. Yoo, S. M. Hong, R. Amir, Z. Yan, E. Kwon, A. Elfick, S. Tomlinson, F. Halbritter, T. Waibel, B.-W. Yun and G. J. Loake, Nat. Biotechnol., 2010, 28, 1213-1217.
20 B.-W. Yun, Z. Yan, R. Amir, S. Hong, Y.-W. Jin, E.-K. Lee and G. J. Loake, Biotechnol. Genet. Eng. Rev., 2012, 28, 47-60.

21 J. B. Joshi, C. B. Elias and M. S. Patole, Chem. Eng. J., 1996, 62, 121-141.

22 Y. H. Zhang, K. M. Jiang, D. G. Qing, B. Huang, J. Y. Jiang, S. M. Wang and C. Y. Yan, RSC Adv., 2017, 7, 12185-12193.

23 R. S. Keri, K. M. Hosamani and H. R. Seetharama Reddy, Catal. Lett., 2009, 131, 321-327.

24 M. M. Heravi, M. Khorasani, F. Derikvand, H. A. Oskooie and F. F. Bamoharram, Catal. Commun., 2007, 8, 1886-1890.

25 J.-X. Yu, P. K. Gulaka, L. Liu, V. D. Kodibagkar and R. P. Mason, ChemPlusChem, 2012, 77, 370-378.

26 L. Moradi and F. Belali, J. Iran. Chem. Soc., 2015, 12, 19271934.

27 X. B. Yang, J. Hou, D. Liu, S. Deng, Z. B. Wang, H. X. Kuang, C. Y. Wang, J. H. Yao, K. X. Liu and X. C. Ma, J. Mol. Catal. B: Enzym., 2013, 88, 1-6.

28 J. K. OH, V. Stöeva, J. Rademacher, R. Farwaha and M. A. Winnik, J. Polym. Sci., Part A: Polym. Chem., 2004, 42, 3479-3489.

29 N. Ding, Z. Xu, B. Huang, L. Han, S. Li and C. Yan, J. Pharm. Sci. Innovation, 2015, 4, 33-35.

30 S. M. Korotkov, I. V. Brailovskaya, A. R. Shumakov and L. V. Emelyanova, J. Bioenerg. Biomembr., 2015, 47, 243-254. 31 G. I. Stafford, P. D. Pedersen, A. K. Jäger and J. V. Staden, $S$. Afr. J. Bot., 2007, 73, 384-390.

32 M. M. Bradford, Anal. Biochem., 1976, 72, 248-254. 